\title{
KEFAHAMAN MENGENAI 'IDDAH DI KALANGAN PELAJAR WANITA POLITEKNIK UNGKU OMAR, IPOH, MALAYSIA
}

\author{
Nabihah Hasinah Abdul Halim dan Che Maryam Ahmad \\ Jabatan Syariah, Fakulti Pengajian Islam, \\ Universiti Kebangsaan Malaysia \\ nabihahasinah90@gmail.com
}

\begin{abstract}
:
This study is conducted to investigated level of understanding among the female students of Politeknik Ungku Omar, Ipoh about 'Iddah (waiting period before a widow or divorced woman may remarry). One set of the questionaire contains 36 items was distributed to 31 respondents. Data gained from the respondents was analyzed using the Statistical Package For Social Sciences (SPSS) version 23 for further statistical analysis. The analysis showed the value of alpha cronbrach of this research tool was $a=0.723$. Research finding that the majority of respondents have a high level of understanding of Iddah with an average overall score of $3.69 \mathrm{~min}$. This suggests that female students at the Polytechnic Ungku Omar mostly very understanding. As such, this understanding must still be maintained through reading or attending lectures and religious lectures. Thus, spiritually as follow religious lectures in addition to increasing the scientific literature is important in helping to understand the tenets of marriage.
\end{abstract}

Keywords: Knowledge, Female Students, Waiting Period ('iddah).

\section{Pendahuluan}

Setiap pasangan yang mendirikan mahligai rumahtangga sangat mengharapkan pengakhiran yang tiada kesudahan. Namun, langit tidak selalunya cerah kerana ada sebahagian perkahwinan yang dibina berakhir dengan penceraian sama ada kerana bercerai hidup mahupun kerana kematian suami yang tercinta. Kesudahan kepada perceraian, tidak habis begitu sahaja kerana terdapat satu lagi tanggungjawab yang perlu dilaksanakan oleh wanita yang diceraikan atau kematian suami iaitu perlaksanaan 'iddah.

'Iddah ialah satu tempoh masa yang telah ditetapkan oleh Allah s.w.t. 
terhadap wanita yang telah diceraikan sama ada kerana bercerai hidup atau bercerai mati yang mana tujuan utamanya adalah bagi membersihkan rahim daripada sebarang benih suami terdahulu, kemudiaannya sebagai menzahirkan rasa sedih atas kematian suami tercinta, serta tempoh masa mengabdikan seluruh jiwa raga kepada Allah s.w.t. ${ }^{1}$

Hukum 'iddah adalah wajib ke atas wanita yang diceraikan dan wanita tersebut hendaklah telah disetubuhi. Begitu juga kewajiban iddah terhadap wanita yang kematian suami iaitu empat bulan sepuluh hari dan tempoh tersebut terlaksana sama ada wanita tersebut telah disetubuhi atau pun belum disetubuhi. ${ }^{2}$ Kewajiban 'iddah terdapat dalam Al-Qur'an Surah al-Baqarah, 2: 228:

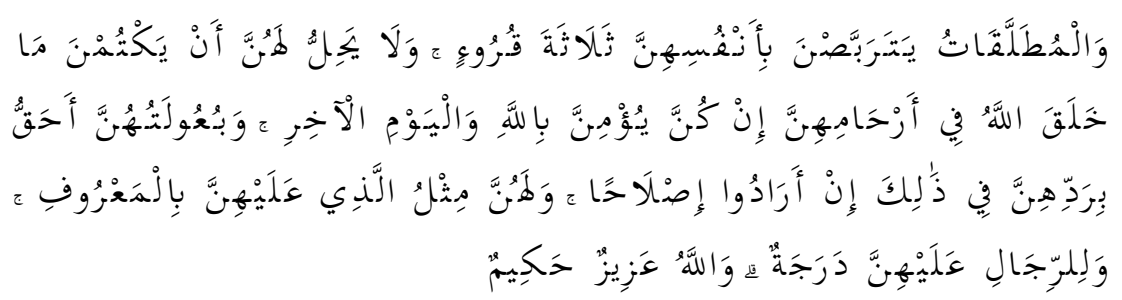

Wanita-wanita yang ditalak handaklah menahan diri (menunggu) tiga kali suci (dari haid). Tidak boleh mereka menyembunyikan apa yang diciptakan Allah dalam rahimnya, jika mereka beriman kepada Allah dan hari akhirat. Dan suami-suaminya berhak merujukinya dalam masa menanti itu, jika mereka (para suami) menghendaki ishlah. Dan para wanita mempunyai hak yang seimbang dengan kewajibannya menurut cara yang ma'ruf. Akan tetapi para suami, mempunyai satu tingkatan kelebihan daripada isterinya. Dan Allah Maha Perkasa lagi Maha

\footnotetext{
${ }^{1}$ Hasan Ayub, Panduan Keluarga Muslim, Terj. Misbah (Jakarta: CENDEKIA Sentra Muslim, 2002), hlm. 403; Siti Zalikhah Md. Nor, Jika Sudah Habis Jodob (Siri UndangUndang Dan Masyarakat) (Kuala Lumpur: Dewan Bahasa dan Pustaka, 2005), hlm. 64;

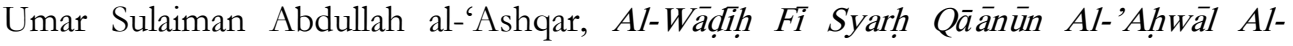
Shakhșiyyah Al-'Urdunī: Raqam 26 Lì 'Am 2010 (Jordan: Dār al-Nafá'is, 2012), hlm. 303; Abdul Rahman al-Jazairi, Fiqh 4 Må̧ab, Terj. H.M. Yusuf Sinaga, H.M. Abdurrahman Saleh Siregar dan H. Muhammad Zuhirsyan, vol. 4 dan 5 (Johor Bahru: Perniagaan Jahabersa, 2011), hlm. 410-411; Zulkifli Mohamad Al-Bakri, Merungkai Permasalahan Tentang Iddah (Nilai: Pustaka Cahaya Kasturi Sdn Bhd, n.d.), hlm. 3.

${ }^{2}$ Saadudin Mus'ad Hilali, Fikh Kerahsian Wanita, Terj. Fauwaz Fadzil Noor (Bandar Baru Bangi: Pelima Media Sdn Bhd, 2010), hlm. 151.
} 


\section{Bijaksana. $^{3}$}

Selain daripada perceraian dan kematian pasangan, kehilangan (mafqud) suami dalam tempoh masa yang lama juga mewajibkan perlaksanaan iddah terhadap isteri. Hal ini adalah berikutan kes mengenai kehilangan pesawat MH370 yang mana isteri tersebut perlu menjalani tempoh iddah selama empat tahun. ${ }^{4}$ Kemudiannya setelah cukup tempoh empat tahun tersebut, isteri tersebut perlu menyambung 'iddah sebanyak empat bulan sepuluh hari sebagai tempoh berkabung seperti kematian. ${ }^{5}$

Sebelum melaksanakan 'iddah, perlu diketahui bahawa iddah mempunyai pelbagai bahagian dan tempoh. Pembahagian 'iddah terdiri kepada dua bahagian iaitu 'iddah perceraian dan 'iddah kematian suami. Setiap daripada pembahagian tersebut mempunyai tempoh contohnya seperti iiddah kerana perceraian dengan bilangan suci (quru') iaitu tiga kali suci bagi wanita yang masih mengalami kitaran haid, tiga bulan jika putus haid atau menopause dan selepas melahirkan anak jika hamil. Manakala iddah kematian suami, isteri tersebut hanya perlu beriddah selama empat bulan sepuluh hari walaupun isteri tersebut masih mempunyai kitaran haid atau sudah menopause (putus haid). Manakala jika isteri tersebut hamil, iddabnya akan berakhir selepas anak yang dikandungnya lahir kedunia iaitu' sama tempoh 'iddah isteri yang bercerai hidup. $^{7}$

\footnotetext{
3 Sheikh Abdullah Basmeih, Tafsir Pimpinan Al-Rabman Kepada Pengertian Al-Quran: (30 Juz), 14th ed. (Kuala Lumpur: Darul Fikir, 2010).

${ }^{4}$ Abdul Rahman Osman, "Isteri Perlu Tunggu Empat Tahun - Mufti," 2014, http://ww1.utusan.com.my/utusan/Dalam_Negeri/20140424/dn_06/Isteriperlutung guempattahunMufti., hlm. 1.

5 Mahmasani Rajab Subhi, Kes-Kes Kehakiman Berkaitan Jenayah Hudud, Qisas Dan Kekeluargaan Di Zaman Al-Khulafä' Al-Rashidin, Terj. Md. Som Sujimon (Kuala Lumpur: IIUM Press, 2009), hlm. 176.

'Abdul Rahman Rukaini, Munakahat: Membina Keluarga Bahagia (Siri Teras Ulum Islamiah) (Selangor: Synergymate Sdn. Bhd, 2001), hlm. 175; Md. Nor, Jika Sudah Habis Jodoh (Siri Undang-Undang Dan Masyarakat), hlm. 65; Mohd Saleh Hj. Ahmad, Perkahwinan Dan Perceraian Dalam Islam (Selangor: Pustaka Haji Abdul Majid Sdn Bhd, 2009), hlm. 230.

7Al-Bakri, Merungkai Permasalahan Tentang Iddah, hlm. 9; JAKIM, "Garis Panduan Ber'iddah Bagi Wanita Yang Bercerai Atau Kematian Suami," Disember 2015, http://www.islam.gov.my/rujukan/garis-panduan/124-garis-panduan-ber-iddah-bagi-
} 
Implikasi dalam kajian ini adalah jika golongan wanita yang beragama Islam kurang memahami hukum hakam 'iddah, besar kemungkinan akan memberi ruang untuk terjadinya masalah yang lebih buruk seperti kes perkahwinan wanita dalam tempoh 'iddah dengan lelaki asing (ajnabi), yang mana ia boleh menyebabkan berlakunya pertikaian mengenai sah ketarafan anak yang bakal dilahirkan hasil daripada perkahwinan tersebut. ${ }^{9}$

Responden kajian adalah daripada kalangan pelajar di Politeknik Ungku Omar. Antara masalah yang dikenalpasti dalam kalangan pelajar di Politeknik Ungku Omar ialah meraka tidak mengaplikasi pelajaran yang dipelajari dalam subjek Pendidikan Islam dalam kehidupan seharian mereka dan pengamalan ajaran Islam masih masih belum mencapai tahap yang tinggi. ${ }^{10}$ Hal ini dibuktikan hanya $62 \%$ responden yang menguasai pengetahuan asas agama Islam dan selebihnya iaitu $58 \%$ pula kurang berminat. ${ }^{11}$ Oleh itu, pengkaji ingin mengkaji bagaimanakah tahap kefahaman mereka terhadap ilmu agama lebihlebih lagi mengenai hukum hakam iddah. Oleh itu, objektif dalam kajian ini adalah untuk mengkaji tahap kefahaman mengenai hukum hakam iddab dalam kalangan pelajar wanita di Politeknik Ungku Omar Ipoh.

\section{Metode}

Kajian ini adalah kajian yang berbentuk kuantitatif yang menggunakan kaedah tinjauan. Instrumen utama dalam kajian ini adalah dengan menggunakan borang soal selidik. Instrumen soal selidik mengandungi lima skala yang terdiri daripada 1 (Sangat Tidak Setuju), 2 (Tidak Setuju), 3 (Tidak Pasti), 4 (Setuju) dan 5 (Sangat Setuju). Sebelum megedarkan borang soal selidik, pengkaji telah mendapatkan kesahan daripda pakar bidang yang

wanita-yang-bercerai-atau-kematian-suami, (telah diekses pada 4 Januari 2017, 2 Disember 2015), hlm. 3.

${ }^{8}$ Basri Ibrahim and Syed Mohd Azmi Syed Abd Rahman, "Pembubaran Perkahwinan Kerana Mengahwini Wanita Dalam Iddah Oleh Mahkamah Tinggi Syariah Kuala Terengganu," Jurnal Syariah 17, no. 3 (2009), hlm. 501-532.

${ }^{9}$ Abd al-Karìm Zaydān, Al-Mufasal Fì Ahkām Al-Mar'āh Wa Al-Bayt Al-Muslimīn Fì AlSharì'ah Al-Islāmïyyah, vol. 9 (Beirut: Mu'assasah al-Risālah, 1993), hlm. 197.

${ }^{10}$ Seri Kartini Jurami and Fariza Md Sham, "Pengamalan Ajaran Islam Dalam Kalangan Pelajar Politeknik Ungku Omar, Ipoh.," Islamiyyat 35, no. 1 (2013), hlm. 2938.

11 Shamsudin Ab Latif, "Kursus Pendidikan Islam Di Politeknik Ungku Omar: Satu Tinjauan Kurikulum Ke Arah Pencapaian Matlamat” (Tesis Sarjana Fakulti Pengajian, Universiti Kebangsaan Malaysia, 1990), hlm. 144-147. 
berkaitan. Seterusnya, sampel kajian diambil daripada pelajar wanita di institusi pengajian awam iaitu di politeknik Ungku Omar Ipoh. Sebanyak 31 borang soal selidik telah diedarkan pada 21 hingga 23 Januari 2017 dan kesemua borang seoal selidik telah dikembalikan dan dijawab dengan baik.

Nilai indeks kebolehpercayaan dalam instrumen kajian telah mencapai tahap kebolehpercayaan yang boleh dipercayai iaitu nilai alpha Cronbach $(\alpha=$ 0.723). Nilai kebolehpercayaan 0.7 ke atas adalah nilai keboleh percayaan yang agak baik mengikut jadual klasifikasi indeks kebolehpercayaan seperti yang tertera dalam rajah 1.1. Hal ini boleh dirujuk juga dalam Jadual 3.6. Oleh itu, instrumen kajian yang dibina adalah sah dan boleh dipercayai, seterusnya boleh digunakan dalam kajian yang sebenar.

Jadual 1.1: Klasifikasi Indeks Kebolehpercayaan

\begin{tabular}{|c|c|}
\hline Indikator & Nilai Alpha Cronbach \\
\hline Sangat Tinggi & $>0.90$ \\
Tinggi & $0.70-0.89$ \\
Sederhana & $0.30-0.69$ \\
Rendah & 0.30 \\
\hline
\end{tabular}

Sumber: Bryman \& Cramer $^{12}$

\section{Dapatan Kajian}

\section{Kefahaman Mengenai 'Iddah dalam Kalangan Pelajar Wanita di Politeknik Ungku Omar, Ipoh}

Bahagian ini membincangkan mengenai dapatan deskriptif nilai min kefahaman mengenai 'iddah yang mengandungi lima konstrak iaitu dari segi pengertian 'iddah, hukum 'iddah, kategori wanita yang wajib ber'iddah, pembahagian dan tempoh iddah serta cara memahami iddah. Skala likert yang digunakan dalam soal selidik adalah dari skala 1 hingga 5. Bagi nilai min setiap item diukur berdasarkan jadual interpertasi skor min dibawah. Penilaian tahap interpertasi skor min adalah seperti Jadual 1.2.

Jadual 1.2: Interpertasi Skor Min Mengikut Tahap

\begin{tabular}{l|l} 
Skor Purata & Interpretasi Tahap
\end{tabular}

\footnotetext{
${ }^{12}$ Farhana Binti Hj Ahmad, "Pengurusan Stres Menurut Al-Quran Dan Al-Sunnah Dalam Kalangan Ibu Tunggal Di Bandar Baru Bangi" (Disertasi Sarjana Pengajian Islam, Universiti Kebangsaan Malaysia, 2015), hlm. 84.
} 


\begin{tabular}{|c|c|}
\hline 1.00 hingga 2.33 & Rendah (R) \\
\hline 2.34 hingga 3.66 & Sederhana (S) \\
\hline 3.67 hingga 5.00 & Tinggi (T) \\
\hline
\end{tabular}

Sumber: (Pallant 2007) ${ }^{13}$

a. Pengertian Tddah

Jadual 1.3 Min, Sisihan Piawai Dan Tahap bagi konstrak Pengertian 'Iddah

\begin{tabular}{|c|l|c|c|c|}
\hline Bil. & \multicolumn{1}{|c|}{ Item } & Min & S.P & Tahap \\
\hline B1.1 & $\begin{array}{l}\text { Iddah berkait rapat dengan kitaran } \\
\text { haid }\end{array}$ & 3.77 & 1.33 & Tinggi \\
\hline B1.2 & $\begin{array}{l}\text { Iddah ialah tempoh menunggu bagi } \\
\text { wanita yang diceraikan. }\end{array}$ & 4.19 & 1.01 & Tinggi \\
\hline B1.3 & $\begin{array}{l}\text { Iddab ialah tempoh menunggu bagi } \\
\text { wanita yang kematian suami. }\end{array}$ & 4.45 & 0.85 & Tinggi \\
\hline B1.4 & $\begin{array}{l}\text { Iddah perlu untuk memastikan } \\
\text { kebersihan rahim wanita daripada } \\
\text { benih suami. }\end{array}$ & 4.55 & 0.85 & Tinggi \\
\hline $\begin{array}{c}\text { B1.5 } \\
\text { (R) }\end{array}$ & $\begin{array}{l}\text { Iddab ialah masa untuk menzahirkan } \\
\text { rasa gembira atas kematian suami. }\end{array}$ & 4.77 & 0.56 & Tinggi \\
\hline $\begin{array}{c}\text { B1.6 } \\
\text { (R) }\end{array}$ & $\begin{array}{l}\text { Iddah ialah tempoh yang diberikan } \\
\text { kepada wanita untuk berkahwin } \\
\text { baru. }\end{array}$ & 3.26 & 1.50 & $\begin{array}{c}\text { Sederhan } \\
\text { a }\end{array}$ \\
\hline $\begin{array}{c}\text { B1.7 } \\
\text { (R) }\end{array}$ & $\begin{array}{l}\text { Tddab ialah tempoh yang } \\
\text { menghalalkan wanita untuk } \\
\text { berkahwin lain }\end{array}$ & 3.13 & 1.67 & $\begin{array}{c}\text { Sederhan } \\
\text { a }\end{array}$ \\
\hline \multicolumn{2}{|c|}{ Pengertian iddah secara keseluruhan } & $\mathbf{4 . 0 2}$ & $\mathbf{3 . 5 9}$ & Tinggi \\
\hline
\end{tabular}

Note: $\mathbf{R}$ (Reverse-scored items)

Jadual 1.3 di atas menunjukkan nilai min, sisihan piawai serta tahap bagi setiap item dalam konstrak pengertian 'iddah. Terdapat tujuh item digunakan bagi mengukur bahagian ini.

13 Nur Syazwani Abd Talib, Kamarulzaman Abd Ghani, and Nur Azuki Yusuff, "Tahap Pengetahuan Dan Sikap Graduan IPT Serta Hubungannya Dengan Minat Terhadap Sejarah: Usaha Awal Memupuk Semangat Cinta Negara," Jurnal Pemikir Pendidikan 7 (2016), hlm. 57-72. 
Dapatan secara terperinci mendapati hanya lima penyataan daripada pengertian 'iddah berada pada tahap yang tinggi iaitu B1.1 $(\min =3.77$, sp $=$ 1.33), item B1.2 $(\mathrm{min}=4.19, \mathrm{sp}=1.01)$, item $\mathrm{B} 1.3(\mathrm{~min}=4.45, \mathrm{sp}=.85)$, item B1.4 $(\min =4.55, \mathrm{sp}=.85)$ dan item B1.5 $(\min =4.77, \mathrm{sp}=0.56)$. Manakala dua penyataan pula berada pada tahap sederhana iaitu pada item B1.6 ( $\mathrm{min}=3.26$, $\mathrm{sp}=1.50)$ dan B1.7 ( $\mathrm{min}=3.13, \mathrm{sp}=1.67)$. Berdasarkan dapatan terperinci di atas menunjukkan, nilai min keseluruhan bagi pengertian iddah adalah (min=4.02) yang mana ia berada pada tahap yang tinggi dan sangat memuaskan.

\section{b. Hukum Tddah}

Jadual 1.4 Nilai Min, Sisihan Piawai Dan Tahap Bagi Konstrak Hukum 'Iddah

\begin{tabular}{|l|l|c|c|c|}
\hline Bil. & \multicolumn{1}{|c|}{ Item } & Min & S.P & Tahap \\
\hline $\begin{array}{l}\text { B2.1 } \\
\text { (R) }\end{array}$ & $\begin{array}{l}\text { Hukum iddab bagi wanita yang } \\
\text { diceraikan adalah harus. }\end{array}$ & 3.26 & 1.03 & $\begin{array}{c}\text { Sederha } \\
\text { na }\end{array}$ \\
\hline B2.2 & $\begin{array}{l}\text { Hukum iddab bagi wanita kematian } \\
\text { suami adalah wajib. }\end{array}$ & 4.52 & 0.77 & Tinggi \\
\hline $\begin{array}{l}\text { B2.3 } \\
\text { (R) }\end{array}$ & $\begin{array}{l}\text { Hukum berkabung (ihdad) atas kematian } \\
\text { suami adalah makruh mengikut syarak. }\end{array}$ & 3.55 & 1.06 & $\begin{array}{c}\text { Sederha } \\
\text { na }\end{array}$ \\
\hline B2.4 & $\begin{array}{l}\text { Wanita dalam iddah haram dipinang jika } \\
\text { dalam tempoh talak yang boleh dirujuk. }\end{array}$ & 4.00 & 0.89 & Tinggi \\
\hline $\begin{array}{l}\text { B2.5 } \\
\text { (R) }\end{array}$ & $\begin{array}{l}\text { Wanita dalam iddah harus berkahwin } \\
\text { baru sehingga tamat tempoh iddahnya }\end{array}$ & 4.03 & 0.98 & Tinggi \\
\hline \multicolumn{2}{|c|}{ Hukum iddah secara keseluruhan } & $\mathbf{3 . 8 7}$ & $\mathbf{2 . 4 1}$ & Tinggi \\
\hline
\end{tabular}

Note: $\mathbf{R}$ (Reverse-scored items)

Jadual 1.4 di atas menunjukkan nilai min, sisihan piawai serta tahap bagi setiap item dalam konstrak hukum iddah. Terdapat lima item digunakan bagi mengukur bahagian ini.

Dapatan secara terperinci mendapati hanya tiga penyataan daripada hukum iddah berada pada tahap yang tinggi iaitu item B2.2 ( $\mathrm{min}=4.53$, $\mathrm{sp}=.77)$, item B2.4 $(\min =4.00, \mathrm{sp}=.89)$ dan item B2.5 ( $\min =4.03, \mathrm{sp}=.98)$. Manakala dua penyataan pula berada pada tahap sederhana iaitu item B2.1 $(\min =3.26, \mathrm{sp}=1.03)$ dan item B2.3 $(\min =3.55, \mathrm{sp}=1.06)$. Berdasarkan dapatan terperinci di atas menunjukkan tahap pengetahuan mengenai hukum iddah di kalangan pelajar wanita adalah di tahap yang tinggi iaitu ( $\min =3.87)$. 
Ini menunjukkan pengetahuan mengenai hukum 'iddah adalah ditahap yang sangat memuaskan.

c. Kategori wanita yang wajib ber'iddah

Jadual 1.5 Nilai Min, Sisihan Piawai Dan Tahap bagi Konstrak Kategori Wanita yang Wajib ber'Iddah

\begin{tabular}{|c|c|c|c|c|}
\hline Bil. & Item & Min & S.P & Tahap \\
\hline $\begin{array}{l}\text { B3.1 } \\
\text { (R) }\end{array}$ & $\begin{array}{l}\text { Wanita yang diceraikan sebelum } \\
\text { disetubuhi. }\end{array}$ & 3.58 & 1.34 & Sederhana \\
\hline B3.2 & $\begin{array}{l}\text { Wanita yang diceraikan dengan talak } \\
\text { raj'ie/ba'in. }\end{array}$ & 3.90 & 0.87 & Tinggi \\
\hline $\begin{array}{l}\text { B3.3 } \\
\text { (R) }\end{array}$ & Wanita yang kematian suami jirannya. & 4.65 & 0.75 & Tinggi \\
\hline B3.4 & $\begin{array}{l}\text { Wanita yang kehilangan suaminya } \\
\text { dalam tempoh seminggu. }\end{array}$ & 3.26 & 1.32 & Sederhana \\
\hline B3.5 & Wanita yang diceraikan ketika hamil. & 3.77 & 1.41 & Tinggi \\
\hline B3.6 & $\begin{array}{l}\text { Wanita yang kematian suaminya serta } \\
\text { telah hamil. }\end{array}$ & 4.06 & 1.06 & Tinggi \\
\hline $\begin{array}{l}\text { B3.7 } \\
(\mathrm{R})\end{array}$ & $\begin{array}{l}\text { Wanita yang dipisahkan oleh } \\
\text { pernikahan fasid sebelum disetubuhi. }\end{array}$ & 3.29 & 1.16 & Sederhana \\
\hline \multicolumn{2}{|c|}{$\begin{array}{l}\text { Kategori wanita yang wajib ber 'iddah } \\
\text { secara keseluruhan }\end{array}$} & 3.78 & 3.69 & Tinggi \\
\hline
\end{tabular}

Note: R (Reverse-scored items)

Jadual 1.5 di atas menunjukkan nilai min, sisihan piawai serta tahap bagi setiap item dalam konstrak kategori wanita yang wajib ber'iddah. Terdapat tujuh item digunakan bagi mengukur bahagian ini.

Dapatan secara terperinci mendapati hanya empat penyataan daripada kategori wanita yang wajib ber'iddah berada pada tahap yang tinggi iaitu item B3.3 $(\min =4.65, \mathrm{sp}=.87)$, item B3.2 $(\mathrm{min}=3.90, \mathrm{sp}=.75)$, item B3.5 $(\mathrm{min}=$ 3.77, $\mathrm{sp}=1.41)$ dan item B3.6 $(\mathrm{min}=4.06, \mathrm{sp}=1.06)$. Manakala tiga penyataan berada pada tahap sederhana iaitu item B3.1 ( $\min =3.58, \mathrm{sp}=1.34)$, item B3.4 $(\min =3.26, \mathrm{sp}=1.32)$ dan B3.7 $(\mathrm{min}=3.29, \mathrm{sp}=1.16)$. Berdasarkan dapatan terperinci di atas menunjukkan tahap pengetahuan mengenai kategori wanita yang wajib ber'iddah di kalangan pelajar wanita adalah di tahap yang tinggi dengan nilai min keseluruhan $(\min =3.78)$. Ini menunjukkan pengetahuan mengenai kategori wanita yang wajib ber'iddah adalah ditahap yang sangat memuaskan. 
d. Pembahagian dan tempoh 'iddah

Jadual 1.6 Nilai Min, Sisihan Piawai Dan Tahap bagi Konstrak

Pembahagian dan Tempoh 'Iddah

\begin{tabular}{|c|c|c|c|c|}
\hline Bil. & Item & Min & S.P & Tahap \\
\hline B4.1 & $\begin{array}{l}\text { Iddab kerana perceraian (cerai } \\
\text { hidup). }\end{array}$ & 4.29 & 0.59 & Tinggi \\
\hline B4.2 & $\begin{array}{l}\text { Iddah kerana kematian suami (cerai } \\
\text { mati). }\end{array}$ & 4.48 & 0.57 & Tinggi \\
\hline B4.3 & Iddab wanita yang hamil & 3.84 & 1.00 & Tinggi \\
\hline B4.4 & Iddah dengan kiraan suci (quru'). & 3.90 & 0.87 & Tinggi \\
\hline $\begin{array}{l}\mathrm{B} 4.5 \\
(\mathrm{R})\end{array}$ & Tddab dengan kiraan hari. & 2.29 & 0.78 & Rendah \\
\hline B4.6 & $\begin{array}{l}\text { Iddab dengan kelahiran atau } \\
\text { keguguran kandungan. }\end{array}$ & 3.52 & 1.18 & Sederhana \\
\hline B4.7 & Iddah wanita yang masih berhaid. & 3.61 & 1.15 & Sederhana \\
\hline B4.8 & Iddab wanita menopause. & 3.00 & 1.39 & Sederhana \\
\hline \multicolumn{2}{|c|}{$\begin{array}{c}\text { Pembahagian dan tempoh iddah } \\
\text { secara keseluruhan }\end{array}$} & 3.61 & 4.22 & Sederhana \\
\hline
\end{tabular}

Note: $\mathbf{R}$ (Reverse-scored items)

Jadual 1.6 di atas menunjukkan dapatan deskreptif nilai min, sisihan piawai serta tahap bagi setiap item dalam konstrak pembahagian dan tempoh iddah. Terdapat lapan item digunakan bagi mengukur bahagian ini.

Dapatan secara terperinci mendapati terdapat empat penyataan daripada pembahagian dan tempoh iddah berada pada tahap yang tinggi iaitu item B4.1 ( $\mathrm{min}=4.29, \mathrm{sp}=.59)$, item B4.2 $(\mathrm{min}=4.48, \mathrm{sp}=.57)$, item B4.3 $(\min =3.84, \mathrm{sp}=1.00)$ dan item B4.4 $(\mathrm{min}=3.90, \mathrm{sp}=.87)$. Manakala tiga penyataan berada pada tahap sederhana iaitu, item B4.6 ( $\min =3.52, \mathrm{sp}=1.18)$ dan item B4.7 ( $\mathrm{min}=3.61, \mathrm{sp}=1.15)$ dan item B4.8 $(\mathrm{min}=3.00, \mathrm{sp}=1.39)$. Kemudiannya satu penyataan yang rendah iaitu item B4.5 ( $\min =2.29, \mathrm{sp}=$ 1.39). Berdasarkan dapatan terperinci di atas menunjukkan tahap pengetahuan mengenai pembahagian dan tempoh 'iddah di kalangan pelajar wanita adalah di tahap yang sederhana dengan nilai min keseluruhan item adalah $(\mathrm{min}=3.61)$. Ini menunjukkan pengetahuan mengenai pembahagian dan tempoh iddah adalah ditahap yang memuaskan.

e. Cara memahami iddah

Jadual 1.7 Nilai Min, Sisihan Piawai Dan Tahap bagi Konstrak Cara Memahami 'iddah 


\begin{tabular}{|c|c|c|c|c|}
\hline Bil. & Item & Min & S.P & Tahap \\
\hline B5.1 & $\begin{array}{l}\text { Saya memahami iddah melalui } \\
\text { pengajian formal. }\end{array}$ & 4.13 & 0.49 & Tinggi \\
\hline B5.2 & $\begin{array}{l}\text { Saya memahami iddah melalui } \\
\text { pengajian tidak formal. }\end{array}$ & 3.03 & 1.11 & Sederhana \\
\hline B5.3 & $\begin{array}{l}\text { Saya memahami iddah melalui } \\
\text { pembacaan. }\end{array}$ & 3.71 & 0.86 & Tinggi \\
\hline B5.4 & $\begin{array}{l}\text { Saya memahami iddah melalui } \\
\text { pemerhatian. }\end{array}$ & 3.06 & 1.12 & Sederhana \\
\hline B5.5 & $\begin{array}{l}\text { Saya memahami ‘iddah melalui } \\
\text { pengalaman. }\end{array}$ & 2.42 & 1.20 & Sederhana \\
\hline B5.6 & $\begin{array}{l}\text { Saya memahami iddah melalui } \\
\text { ceramah-ceramah yang dihadiri. }\end{array}$ & 3.65 & 0.84 & Sederhana \\
\hline B5.7 & $\begin{array}{l}\text { Saya memahami iddah melalui media } \\
\text { sosial. }\end{array}$ & 3.32 & 1.01 & Sederhana \\
\hline B5.8 & $\begin{array}{l}\text { Saya memahami iddah melalui media } \\
\text { rasmi di television. }\end{array}$ & 3.42 & 0.85 & Sederhana \\
\hline B5.9 & $\begin{array}{l}\text { Saya memahami } i d d a h \text { daripada } \\
\text { rancangan radio. }\end{array}$ & 3.26 & 1.03 & Sederhana \\
\hline & $\begin{array}{r}\text { Cara memahami } \begin{array}{r}\text { iddah secara } \\
\text { keseluruhan }\end{array} \\
\end{array}$ & 3.33 & 4.24 & Sederhana \\
\hline
\end{tabular}

Jadual 1.7 di atas menunjukkan dapatan deskreptif nilai min, sisihan piawai serta tahap bagi setiap item dalam konstrak cara memahami iddah. Terdapat sembilan item digunakan bagi mengukur bahagian ini.

Dapatan secara terperinci mendapati dua penyataan daripada cara memahami iddah berada pada tahap yang tinggi iaitu item B5.1 ( $\mathrm{min}=4.13$, $\mathrm{sp}=.49)$ dan item B5.3 ( $\mathrm{min}=3.71, .86)$. dan Manakala tujuh penyataan berada pada tahap sederhana iaitu pada item B5.2 $(\mathrm{min}=3.03, \mathrm{sp}=1.11)$, item B5.4 $(\mathrm{min}=3.06, \mathrm{sp}=1.12)$, item B5.5 $(\mathrm{min}=2.42, \mathrm{sp}=1.20)$, item B5.6 $(\mathrm{min}=3.65$, $\mathrm{sp}=.84)$, item B5.7 $(\min =3.32,1.01)$, item B5.8 $(\min =3.42, \mathrm{sp}=.85)$ dan item B5.9 $(\min =3.26, \mathrm{sp}=1.03)$. Berdasarkan dapatan terperinci di atas menunjukkan tahap cara memahami 'iddah di kalangan pelajar wanita adalah di tahap yang sederhana dengan nilai min bagi keseluruhan item (min=3.33). Ini menunjukkan pengetahuan mengenai cara memahami iddah adalah ditahap yang memuaskan. 


\section{Pembahasan}

Berdasarkan dapatan kajian yang diperolehi, kefahaman iddah dalam kalangan pelajar wanita berada pada tahap yang tinggi $(\min =3.69)$. Hal ini boleh dirujuk dalam jadual 7 .

Jadual 1.8 Nilai keseluruhan setiap konstrak

\begin{tabular}{|c|l|c|c|}
\hline Bil. & Konstrak & Min & Tahap \\
\hline B1 & Pengertian Tddah & 4.02 & Tinggi \\
\hline B2 & Hukum Tddab & 3.87 & Tinggi \\
\hline B3 & Kategori Wanita yang Wajib Tddah & 3.78 & Tinggi \\
\hline B4 & Pembahagian dan Tempoh Tddah & 3.61 & Sederhana \\
\hline B5 & Cara Memahami Tddab & 3.33 & Sederhana \\
\hline & Nilai Min keseluruhan konstrak & $\mathbf{3 . 6 9}$ & Tinggi \\
\hline
\end{tabular}

Sekiranya diperhati dengan teliti bagi setiap konstrak, terdapat item-item yang mempunyai skor min yang tinggi dan sederhana seperti pada pengertian ‘ddah, hukum 'iddah, kategori wanita yang wajib ber'iddah, pembahagian serta tempoh iddah dan cara memahami 'iddah.

Bagi konstrak pengertian iddah, penyataan B1.6 ('Iddah ialah tempoh yang diberikan kepada wanita untuk berkahwin baru) dan B1.7 (Iddah ialah tempoh yang menghalalkan wanita untuk berkahwin lain) masing-masing dengan tahap yang sederhana iaitu $(\min =3.26)$ untuk item B1.6 dan $(\min =3.13)$ untuk item B1.7. Hal ini menunujukkan masih ramai responden yang kurang faham mengenai wanita dalam tempoh iddah haram berkahwin baru. Pengharaman wanita dalam tempoh 'iddah berkahwin adalah bagi menjaga nasab keturunan. ${ }^{14}$

Manakala pada konstrak hukum 'iddah pula, minoriti berada pada tahap yang sederhana iaitu pada item B2.1 (hukum iddah bagi wanita yang diceraikan adalah harus) dan B2.3 (Hukum berkabung (ibdad) atas kematian suami adalah makruh mengikut syarak) iaitu $(\mathrm{min}=3.26)$ bagi item B2.1 dan $(\min =3.55)$ bagi item B2.3. Oleh itu, terdapat sebilangan responden masih kurang tahu mengenai hukum 'iddah bagi wanita yang diceraikan dan hukum iddah bagi wanita yang kematian suami. Hukum 'iddah adalah wajib sepertimana yang telah disepakati oleh jumhur ulama'. ${ }^{15}$ Begitu juga hukum wajib bagi wanita yang

\footnotetext{
${ }^{14}$ Subhi, Kes-Kes Kehakiman Berkaitan Jenayah Hudud, Qisas Dan Kekeluargaan Di Zaman Al-Khulafä' Al-Rashidin, hlm. 171.

${ }^{15}$ al-Saìyyid Sābiq, Fiqh Al-Sunnah, 7th ed. (al-Kaherah: Dār al-Hadith, 2010), 672.
} 
kematian suami untuk berkabung selama empat bulan sepuluh hari. ${ }^{16}$

Begitu juga pada konstrak kategori wanita yang wajib ber'iddah, item B3.1 (Wanita yang diceraikan sebelum disetubuhi), B3.4 (Wanita yang kehilangan suaminya dalam tempoh seminggu) serta item B3.7 (Wanita yang dipisahkan oleh pernikahan syubhah sebelum disetubuhi) masing-masing adalah item yang berada pada tahap yang sederhana dengan nilai min setiap item iaitu B3.1 $(\min =3.58)$, item B3.4 $(\min =3.26)$ dan item B3.7 $(\min =3.29)$. hal ini menunjukkan sebilangan responden yang masih kurang tahu bahawa wanita yang diceraikan dengan talak raj'ie dan talak ba'in perlu ber'iddah. Manakala jika wanita tersebut diceraikan sebelum disetubuhi (janda berhias), tiada kewajipan 'iddah baginya. 'Iddah wajib dilaksanakan ke atas isteri yang telah diceraikan sama ada kerana talak raj'ie iaitu talak yang boleh dirujuk kembali, talak ba'in iaitu talak tiga atau kbulu' (tebus talak) serta penceraian kerana kematian suami. ${ }^{17}$ Wanita yang kehilangan suami wajib ber'iddah jika kehilangan suaminya itu memakan masa lebih daripada empat tahun dengan memastikan terdapat pengkhabaran yang pasti mengenai berita kematian suaminya. ${ }^{18}$ Seterusnya dalam perihal pernikahan fasid atau dikenali sebagai wati syubhah, wanita tersebut diwajibkan melaksanakan 'iddah walaupun wanita tersebut belum berkahwin (anak dara), janda, isteri orang dan hikmah pensyariatan iddah adalah sebagai tanda menghormati air mani yang diciptakan Allah s.w.t.. ${ }^{19}$ dan jika wanita tersebut belum sempat disetubuhi, tiada kewajipan 'iddah baginya.

Bagi konstrak pembahagian dan tempoh 'iddah, min keseluruhan dalam konstrak ini dilihat sederhana kerana terdapat satu item berada pada nilai min yang rendah tiga item pula dalam konstruk tersebut mendapat nilai min yang sederhana dan iaitu pada item B4.5 (Iddah dengan kiraan hari), B4.6 ('Iddah dengan kelahiran atau keguguran kandungan), B4.7 (Iddah wanita yang masih berhaid) serta B4.8 (Tddah wanita menopause) dengan masing-masing mendapat nilai $\min (\min =2.29)$ pada item B4.5, $(\min =3.52)$ bagi item B4.6, $(\min =3.61)$ pada item B4.7 dan $(\min =3.00)$ pada item B4.8. hal ini kerana sebilangan responden masih kurang mengetahu mengenai pembahagian dan tempohtempoh 'iddah. Bagi item B4.5, tempoh 'iddah mempunyai 3 jenis iaitu 'iddah

\footnotetext{
${ }^{16}$ Abi 'Abdullah bin Ismail bin Ibrahim al-Bukhāri, Șậ̣̣h Al-Bukhāri (Al-Azhar: Alfa, 2011), hlm. 155; Hilali, Fikh Kerahsian Wanita, hlm. 152.

${ }^{17}$ Muhammad 'Uqlah, Nizhām Al-'Usrah Fì Al-Isläm, vol. 3 (Amman: Maktabah alRisālah al-Hadis, 2002), hlm. 286.

${ }^{18}$ Ayub, Panduan Keluarga Muslim, hlm. 419.

${ }^{19}$ Mohd Saleh Hj. Ahmad, Perkahwinan Dan Perceraian Dalam Islam, hlm. 223.
} 
dengan kiraan bulan iaitu tiga bulan bagi wanita yang putus haid (menopause), tiga kali suci atau tiga kali haid bagi wanita yang masih berhaid, empat bulan sepuluh hari bagi wanita yang kematian suami serta selepas melahirkan anak jika wanita tersebut hamil. ${ }^{20}$ Manakala bagi iddah kelahiran dan keguguran pula, jumhur ulama' telah bersepakat bahawa tempoh 'iddah bagi wanita yang hamil adalah selepas melahirkan anaknya. ${ }^{21}$ Begitu juga jika kandungan yang dilahirkan itu adalah mudhghah (seketul daging) yang fizikalnya menyerupai manusia yang mana telah disahkan oleh pakar perbidanan, maka hukum iddahnya akan berakhir selepas melahirkan kandungannya itu. ${ }^{22}$

Manakala bagi konstrak cara memahami iddah, kebanyakan reponden memahami 'iddah daripada pengajian-pengajian formal dan melalui bahan-bahan bacaan ilmiah. Namun, jika dilihat melalui ceramah agama yang dihadiri masih berada ditahap yang sederhana iaitu ( $\mathrm{min}=3.65)$. Begitu juga melalui media rasmi $(\min =3.42)$, media sosial $(\min =3.32)$ dan siaran radio $(\min =3.26)$ masingmasingnya adalah ditahap yang sederhana. Manakala dari segi pemerhatian dan pengalaman mendapat nilai min yang sederhana iaitu $(\min =3.6)$ bagi item B4.5 dan (min=5.5) bagi item B5.5.

Secara keseluruhannya, majoriti responden mempunyai tahap kefahaman yang tinggi berkaitan dengan 'iddah dengan purata nilai min keseluruhannya sebanyak 3.69. Hal ini menunjukkan bahawa pelajar-pelajar wanita di Politeknik Ungku Omar, Ipoh kebanyakkannya memahami dan mengetahui hukum hakam berkaitan 'iddah.

\section{Simpulan}

Kepentingan memahami 'iddah bukan sahaja terletak pada bahu wanita yang sudah berkahwin, malah golongan wanita yang belum berkahwin juga perlu memahaminya. Hukum hakam 'iddah perlu difahami dengan teliti kerana hukumnya adalah wajib dan jika meninggalkannya adalah berdosa besar. Kewajipan melaksanakan ‘ddah adalah bertujuan bagi menjaga nasab keturunan.

${ }^{20}$ Rukaini, Munakahat: Membina Keluarga Bahagia (Siri Teras Ulum Islamiah), hlm. 175.

${ }^{21}$ Md. Nor, Jika Sudah Habis Jodoh (Siri Undang-Undang Dan Masyarakat), hlm. 66; Hilali, Fikh Kerabsian Wanita, hlm. 156.

${ }^{22}$ Sham al-Din al-Khatib al-Sharbani, Mughni Al-Muhtāj "ilā Ma"rifah Ma'āni 'Alfä AlManhāj (al-Kaherah: Dār al-Fikr, 1998), hlm. 384-393; al-Bājūri al-Sheikh Ibrahim, Hāshìyyah Al-Bājūrī 'alā Ibn Qāsim Al-Gazi (Singapura: t.t.t., t.th.), hlm. 168-172; Abu Bakar al-Bakri Shata al-Dimyātị, 'I'ānah Al-Ṭälibīn "alā Hal Al-Fāz Fath Al-Mu"aìn Lil Malibārì (Al-Kaherah: Dār "Ihya" al-Kutub al-"Arabiah, t.th.), hlm. 39-42. 
Berikutan itu, jika seseorang wanita telah mendirikan rumah tangga, namun jodohnya tidak panjang akibat diceraikan sama ada bercerai hidup mahu pun bercerai mati, mereka perlu ber'iddah dengan tempoh yang telah ditetapkan sama ada tiga kali suci bagi yang masih berhaid, tiga bulan bagi yang putus haid, selepas melahirkan anak bagi yang hamil dan empat bulan sepuluh hari bagi wanita yang kematian suami. Hal ini kerana, tempoh berkenaan sebagai langkah menjaga nasab keturunan dan selepas tamatnya tempoh iddah mereka berhak untuk berkahwin dengan sesiapa sahaja yang disukai.

Dapatan kajian ini menunjukkan kefahaman mengenai iddah dari segi pengertiannya oleh pelajar wanita adalah tinggi. Begitu juga tahap kefahaman dari segi hukum 'iddah dan kategori wanita yang wajib ber'iddah juga adalah tinggi. Manakala tahap kefahaman pelajar wanita dari segi pebahagian dan tempoh iddah serta cara memahami iddah adalah ditahap yang sederhana. Sehubungan itu, kefahaman mengenai hukum hakam iddah perlu dipertingkatkan lagi dari semasa ke semasa sama ada secara tidak langsung atau langsung, melalui pembacaan atau menghadiri kuliah-kuliah dan ceramahceramah agama. Justeru, pengisian rohani seperti mengikuti kuliah-kuliah agama disamping memperbanyakkan bahan bacaan ilmiah adalah penting dalam membantu memahami hukum hakam dalam perkahwinan. Seterusnya, pengkaji mengharapkan agar kajian ini menjadi titik tolak kepada kajian yang seterusnya khususnya dalam memberi penekanan terhadap kesan-kesan setelah berlakunya pembubaran perkahwinan.

\section{Daftar Pustaka}

Ab Latif, Shamsudin. "Kursus Pendidikan Islam Di Politeknik Ungku Omar: Satu Tinjauan Kurikulum Ke Arah Pencapaian Matlamat." Tesis Sarjana Fakulti Pengajian, Universiti Kebangsaan Malaysia, 1990.

Abd Talib, Nur Syazwani, Kamarulzaman Abd Ghani, and Nur Azuki Yusuff. "Tahap Pengetahuan Dan Sikap Graduan IPT Serta Hubungannya Dengan Minat Terhadap Sejarah: Usaha Awal Memupuk Semangat Cinta Negara." Jurnal Pemikir Pendidikan 7 (2016).

Al-Bakri, Zulkifli Mohamad. Merungkai Permasalahan Tentang Iddah. Nilai: Pustaka Cahaya Kasturi Sdn Bhd, 2014.

'Ashqar, Umar Sulaiman Abdullah al-. Al-Wădịh Fì Syarh Qāānūn Al'Ahwāl Al-Shakhṣìyyah Al-'Urdunī: Raqam 26 Lì 'Am 2010. Jordan: Dār al-Nafà'is, 2012. 
Ayub, Hasan. Panduan Keluarga Muslim. Terj. Misbah. Jakarta: CENDEKIA Sentra Muslim, 2002.

Basmeih, Sheikh Abdullah. Tafsir Pimpinan Al-Rahman Kepada Pengertian AlQuran: (30 Juश). 14th ed. Kuala Lumpur: Darul Fikir, 2010.

Bukhāri, Abi 'Abdullah bin Ismail bin Ibrahim al-. Șaḥịh Al-Bukhāri. AlAzhar: Alfa, 2011.

Dimyātị, Abu Bakar al-Bakri Shata al-. 'I'ānah Al-Ṭālibīn "alā Hal Al-Fāz Fath Al-Mu"aīn Lil Malïbārí. Al-Kaherah: Dār "Ihya" al-Kutub al'Arabiah, t.th.

Farhana Binti Hj Ahmad. "Pengurusan Stres Menurut Al-Quran Dan AlSunnah Dalam Kalangan Ibu Tunggal Di Bandar Baru Bangi." Disertasi Sarjana Pengajian Islam, Universiti Kebangsaan Malaysia, 2015.

Hilali, Saadudin Mus'ad. Fikh Kerabsian Wanita. Terj. Fauwaz Fadzil Noor. Bandar Baru Bangi: Pelima Media Sdn Bhd, 2010.

Ibrahim, al-Bājūri al-Sheikh. Hāàshìyyah Al-Bājūrì 'alā Ibn Qāsim Al-Gazi. Singapura: t.t.t., t.th.

Ibrahim, Basri, and Syed Mohd Azmi Syed Abd Rahman. "Pembubaran Perkahwinan Kerana Mengahwini Wanita Dalam Iddah Oleh Mahkamah Tinggi Syariah Kuala Terengganu." Jurnal Syariab 17, no. 3 (2009).

JAKIM. "Garis Panduan Ber'iddah Bagi Wanita Yang Bercerai Atau Kematian Suami," Disember 2015. http://www.islam.gov.my/rujukan/garispanduan/124-garis-panduan-ber-iddah-bagi-wanita-yang-bercerai-ataukematian-suami.

Jazairi, Abdul Rahman al-. Fiqh 4 Mą̧hab. Terj. H.M. Yusuf Sinaga, H.M. Abdurrahman Saleh Siregar dan H. Muhammad Zuhirsyan. Vol. 4 dan 5. Johor Bahru: Perniagaan Jahabersa, 2011.

Jurami, Seri Kartini, and Fariza Md Sham. "Pengamalan Ajaran Islam Dalam Kalangan Pelajar Politeknik Ungku Omar, Ipoh.” Islamiyyat 35, no. 1 (2013).

Md. Nor, Siti Zalikhah. Jika Sudah Habis Jodoh (Siri Undang-Undang Dan Masyarakat). Kuala Lumpur: Dewan Bahasa dan Pustaka, 2005.

Mohd Saleh Hj. Ahmad. Perkahwinan Dan Perceraian Dalam Islam. Selangor: Pustaka Haji Abdul Majid Sdn Bhd, 2009. 
Osman, Abdul Rahman. "Isteri Perlu Tunggu Empat Tahun - Mufti," 2014. http://ww1.utusan.com.my/utusan/Dalam_Negeri/20140424/dn_06/ IsteriperlutungguempattahunMufti.

Rukaini, Abdul Rahman. Munakahat: Membina Keluarga Bahagia (Siri Teras Ulum Islamiah). Selangor: Synergymate Sdn. Bhd, 2001.

Sābiq, al-Saìyyid. Fiqh Al-Sunnah. 7th ed. al-Kaherah: Dār al-Hadith, 2010.

Sharbani, Sham al-Din al-Khatib al-. Mughni Al-Muhtäj "ilà Ma"rifah Ma'āni 'Alfäz Al-Manhāj. al-Kaherah: Dār al-Fikr, 1998.

Subhi, Mahmasani Rajab. Kes-Kes Kehakiman Berkaitan Jenayah Hudud, Qisas Dan Kekeluargaan Di Zaman Al-Khulafä' Al-Rashidin. Terj. Md. Som Sujimon. Kuala Lumpur: IIUM Press, 2009.

'Uqlah, Muhammad. Nizhām Al-'Usrah Fì Al-Islām. Vol. 3. Amman: Maktabah al-Risālah al-Ḥadis, 2002.

Zaydān, Abd al-Karìm. Al-Mufașal Fì Ahkām Al-Mar'āh Wa Al-Bayt AlMuslimin Fì Al-Shari'ah Al-Islämíyyah. Vol. 9. Beirut: Mu'assasah al-Risālah, 1993. 